Volume : 06
Nomor $: 03$
Bulan $:$ September
Tahun
http 2020
$:$ //ejurnal.pps.ung.ac.id/index.php/Aksara

\title{
Analisis Ketimpangan Ekonomi Provinsi Bali Tahun 2019
}

\author{
Ukhti Luthfiyah, Amandus Jong Tallo \\ Fakultas Teknik dan Ilmu Komputer, Univeritas Bakrie \\ ukhti.luthfiyah@gmail.com; mandustallo@gmail.com
}

Received: 08 Juli 2020; Revised: 21 Agustus 2020; Accepted: 28 Agustus 2020

DOI: http://dx.doi.org/10.37905/aksara.6.2.97-102.2020

\begin{abstract}
Abstrak
Provinsi Bali memiliki perbedaan kuantitas dan kualitas sumberdaya alam pada masingmasing wilayah kabupaten/kota. Perbedaan tersebut menyebabkan adanya ketimpangan atau kesenjangan antar kabupaten/kota. Tujuan dari penelitian ini adalah untuk menganalisis ketimpangan ekonomi menurut wilayah dan sektor lapangan usaha perkabupaten/kota di Provinsi Bali. Data pada penelitian ini menggunakan data sekunder PDRB Atas Harga Konstan dari tahun 2015-1019 yang diambil dari BPS setiap kabupaten/kota di Provinsi Bali. Penelitian ini ditentukan dengan metode analisis tipologi klassen dan penentuan ketimpangan antarwilayah menggunakan Indeks Williamson. Hasil dari penelitian ini menunjukkan bahwa Provinsi Bali memiliki nilai ketimpangan Indeks Williamson 0.26 pada tahun 2019 yang menunjukkan nilai yang cukup baik dengan adanya penurunan tingkat ketimpangan ekonomi dibandingkan dengan penelitian di tahun sebelumnya. Pemerataan pembangunan tetap harus diperhatikan dengan memfokuskan pada wilayah dan sektor yang masih termasuk tertinggal atau terbelakang, sehingga proses pembangunan dapat terjadi pada semua wilayah kabupaten/kota di Provinsi Bali.
\end{abstract}

\section{Kata Kunci}

Bali, PDRB, Tipologi Klassen, Indeks Williamson, Ketimpangan Ekonomi.

\section{Pendahuluan}

Indonesia memiliki beberapa provinsi yang memiliki karakteristik wilayah yang bermacam-macam beserta potensi sumberdayanya masing-masing. Provinsi Bali sebagai salah satu provinsi di Indonesia yang mempunyai sumberdaya cukup berlimpah (Yuendini et al, 2019). Bali terletak pada posisi strategis di tengah Indonesia yang diapit oleh benua dan dua samudra yang terkenal. Bali terkenal dengan destinasi wisata yang menarik banyak turis dari dalam maupun luar negeri. Setiap tahunnya angka wisatawan terus menerus naik, sehingga hal ini menyebabkan peningkatan substansial dalam perekonomian Bali (Wiranatha \& Suryawardani, 2017).

Kebijakan perekonomian setiap daerah memiliki perbedaan struktur ekonomi yang menentukan sektor unggulan sesuai dengan kemampuan dan letak wilayah. Sektor unggulan dapat dipilih dari sektor dasar yang ada pada masing-masing daerah dalam pengembangan wilayah. Peran dalam pasar pengiriman keluar daerah dapat terus berkembang dengan permintaan tanpa batas, sehingga dapat meningkatkan perekonomian serta perekrutan tenaga kerja dalam jumlah besar (Wiguna \& Budhi, 2019). 
Berdasarkan Raeskyesa et al, (2019) dalam penelitiannya yang menggunakan data dari tahun 2010 hingga 2016 terdapat kesenjangan signifikan antarwilayah di Provinsi Bali. Daerah yang termasuk pertumbuhan pembangunan dengan pendaptan per kapita tertinggi yaitu kabupaten Badung dan kota Denpasar. Sektor ekonomi unggulan yang dimiliki kabupaten Badung diantaranya pada sektor konstruksi; makanan dan akomodasi; serta komunikasi dan informasi. Kota Denpasar memiliki sektor ekonomi unggulan pada sektor listrik dan gas; konstruksi; perdagangan, retail, dan reparasi; finansial dan jasa asuransi; real estate; jasa pendidikan; serta jasa kesehatan dan social. Daerah lainnya yang mengalami perkembangan yang rendah diantaranya kabupaten Klungkung, Jembrana, Bangli, Karangasem, dan Tabanan.

Kesenjangan signifikan antar daerah berdasarkan penelitian sebelumnya tersebut menunjukkan perkembangan antar daerah yang tidak merata yang dapat menghambat kinerja di masa depan, maka sangat penting memahami karakteristik ekonomi setiap daerah dalam meningkatkan produktivitas ekonomi. Hal ini dapat dijadikan gambaran karakteristik ekonomi yang mempengaruhi tingkat ketimpangan antarwilayah di Provinsi Bali.

\section{Metode}

Lokasi penelitian yang diambil termasuk dalam wilayah Provinsi Bali dengan menggunakan data PDRB atas dasar harga konstan tahun 2015-2019 diakses melalui website BPS. Pengembangan dilakukan dengan mengidentifiksi sektor basis/sektor dasar, kemudian ditentukan sektor unggulan berdasarkan pada potensi ekonomi daerah terkait kontribusi sektor dalam bentuk skala dan pertmbuhan ekonomi daerah. Semakin besar peran sektor, maka semakin besar pula peningkatan ekonomi, baik berpotensi dalam persaingan relative sektor ekonomi daerah maupun dibandingkan dengan wilayah yang lebih luas. Penentuan sektor potensial dengan menggunakan metode analisis tipologi klassen dan pengukuran ketimpangan wilayah dengan Indeks Williamson (Tallo et al, 2018).

\subsection{Analisis Tipologi Klassen}

Posisi sektor ekonomi wilayah perencanaan di Provinsi Bali yang diketahui menurut struktur dan laju pertumbuhan ekonomi antarwilayah yang lebih luas.

Tabel 1. Klasifikasi Antarwilayah Menurut Tipologi Klassen

\begin{tabular}{|c|c|c|}
\hline \multicolumn{1}{|c|}{ Rata-rata kontribusi sektoral } & Yij $\geq \mathrm{Yi}$ & yij $>\mathrm{Yi}$ \\
\hline Rata-rata laju pertumbuhan sektor & & \\
\hline rij $>\mathrm{Ri}$ & Unggulan & Berkembang \\
\hline $\mathrm{Rij}<\mathrm{Ri}$ & Potensial & Tertinggal \\
\hline
\end{tabular}

Keterangan:

- rij : Nilai rerata laju pertumbuhan sektor $\mathrm{i}$ di wilayah perencanaan $\mathrm{j}$

- Ri : Nilai rerata laju pertumbuhan sektor i di wilayah yang lebih luas

- yij : Nilai rerata kontribusi i terhadap ekonomi wilayah perencanaan $\mathrm{j}$

- Yi : Nilai rerata kontribusi sektor i terhadap wilayah yang lebih luas

2.2 Pengukuran Ketimpangan Wilayah

Pengukuran ketimpangan ekonomi antarwilayah menggunakan data PDRB 
per kapita Provinsi Bali dianalisis dengan metode Indeks Williamson. Semakin besar angka Indeks Williamson, berarti semakin tinggi kesenjangan ekonomi antarwilayah, begitupula sebaliknya (Sukwika, 2018). Indeks Williamson dengan menggunakan rumus berikut :

Keterangan:

$$
\mathrm{IW}=\frac{\sqrt{\sum_{i}^{n}=0(Y i-Y)^{2}\left(\frac{f i}{n}\right)}}{Y}
$$

fi $=$ Jumlah penduduk kabupaten i

$\mathrm{n}=$ Jumlah penduduk Provinsi

Yi = Angka PDRB per kapita di kabupaten $\mathrm{i}$

$\mathrm{Y}=$ Angka PDRB rata-rata per kapita di Provinsi

\section{Hasil dan Pembahasan}

Penilaian dilakukan dalam 3 bagian diantaranya; pertama, analisis tipologi klassen. Kedua, penentuan ketimpangan antarwilayah dengan menggunakan analisis Indeks Williamson menggunakan data PDRB pada harga konstan tahun 2015-2019 yang telah dirata-ratakan, yaitu pertumbuhan dan data PDB per kapita di setiap kabupaten/kota dalam wilayah Provinsi Bali. Ketiga, analisis hubungan antara tipologi wilayah dan sektor-sektor unggulan potensial sebagai solusi atas ketimpangan atau kesenjangan ekonomi di wilayah Provinsi Bali yang ditemukan dari analisis Indeks Williamson.

\section{Hasil}

\subsection{Penentuan Tipologi Klassen}

Wilayah Provinsi Bali digolongkan sebagai daerah maju tetapi tertinggal. Ada 3 daerah yang termasuk daerah maju dan tumbuh cepat, ada 4 daerah relatif tertinggal ,serta 2 daerah maju tapi tertekan (tabel 5).

Tabel 5. Klasifikasi Antarwilayah di Provinsi Bali pada tahun 2019

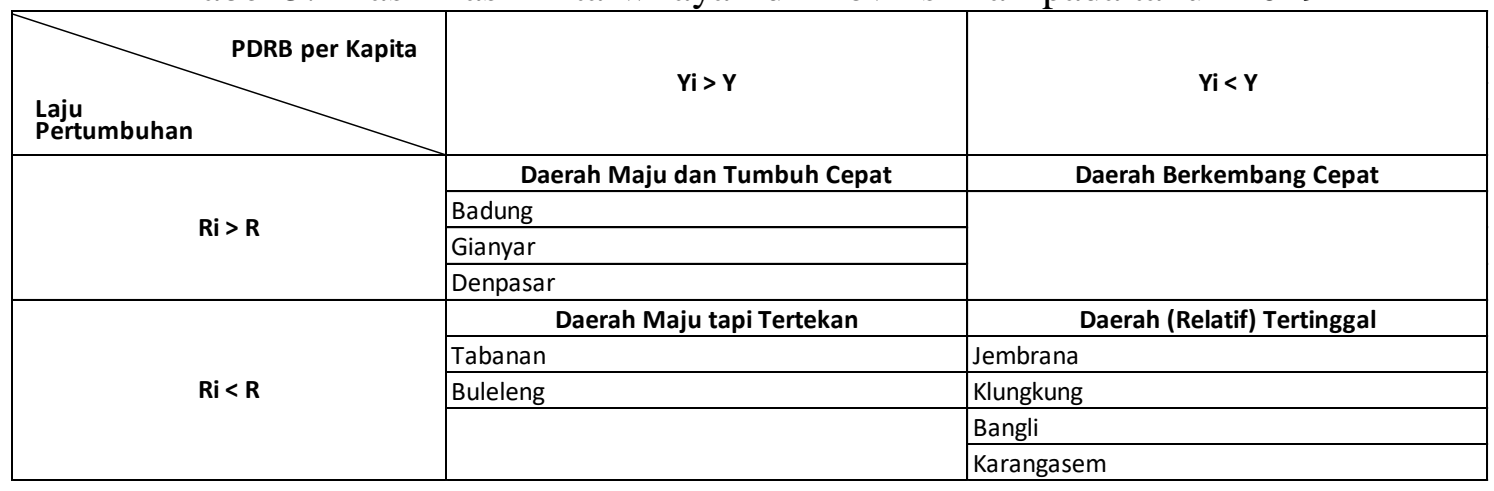

Klasifikasi sektor lapangan usaha di Provinsi Bali terdapat 4 golongan, diantaranya; sektor-sektor unggulan (prima), sektor berkembang, sektor potensial dan sektor terbelakang. 
Tabel 6. Klasifikasi Sektor di Provinsi Bali pada tahun 2019

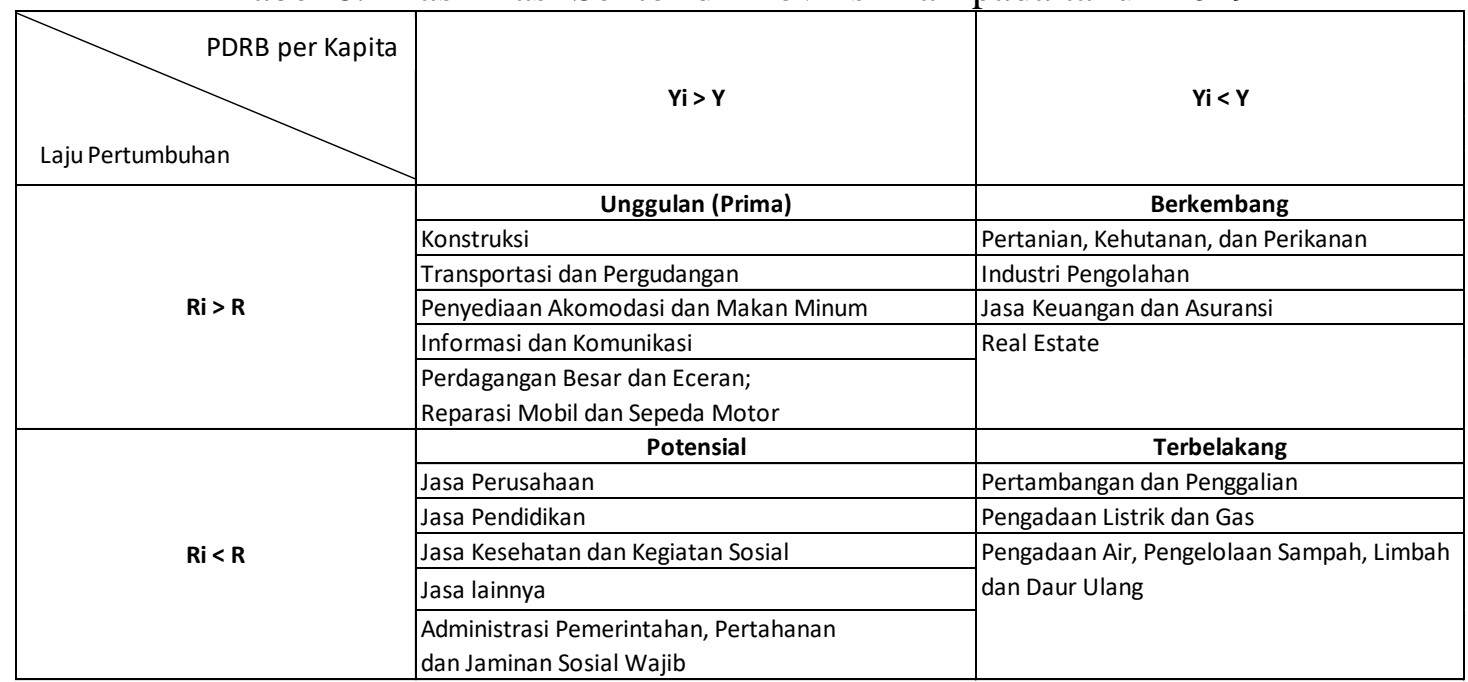

3.2. Analisis Ketimpangan Indeks Williamson (IW)

Provinsi Bali memiliki nilai ketimpangan Indeks Williamson 0.26 pada tahun 2019. Hal ini sangat berpengaruh pada pengembangan wilayah masa depan. Kesembilan kabupaten/kota tersebut diantaranya; Kabupaten Jembrana, Tabanan, Badung, Gianyar, Klungkung, Bangli, Karangasem, Buleleng dan Kota Denpasar. (tabel 7)

Tabel 7. Indeks Williamson Provinsi Bali per Kabupaten/Kota 2019

\begin{tabular}{|c|c|c|c|c|c|c|}
\hline No. & Kabupaten/Kota & yi & fi & $(y i-y)^{\wedge} 2$ & fi/n & $\left((y i-y)^{\wedge} 2\right) *(f i / n)$ \\
\hline 1 & Kab. Jembrana & 33877.63 & 278.10 & 1587493.49 & 0.06 & 101796.66 \\
\hline 2 & Kab. Tabanan & 35425.80 & 445.70 & 83065.25 & 0.10 & 8536.55 \\
\hline 3 & Kab. Badung & 55708.40 & 670.20 & 423158174.58 & 0.15 & 65392471.26 \\
\hline 4 & Kab. Gianyar & 37185.86 & 512.20 & 4195423.17 & 0.12 & 495491.19 \\
\hline 5 & Kab. Klungkung & 33460.30 & 179.10 & 2813302.32 & 0.04 & 116180.32 \\
\hline 6 & Kab. Bangli & 20188.56 & 227.30 & 223473507.13 & 0.05 & 11712404.75 \\
\hline 7 & Kab. Karangasem & 26727.80 & 416.60 & 70724655.85 & 0.10 & 6793767.81 \\
\hline 8 & Kab. Buleleng & 35479.09 & 660.60 & 116624.36 & 0.15 & 17764.31 \\
\hline 9 & Kota Denpasar & 38184.87 & 947.10 & 9285902.73 & 0.22 & 2027872.09 \\
\hline \multicolumn{2}{|r|}{ Provinsi Bali } & 35137.59 & 4336.90 & & Total & 86666284.96 \\
\hline \multirow{2}{*}{\multicolumn{2}{|c|}{ Rata-rata (y) }} & 35137.59 & 481.88 & & Akar & 9309.47 \\
\hline & & & & & IW & 0.26 \\
\hline
\end{tabular}

\section{Pembahasan}

\subsection{Analisis Ketimpangan Antarwilayah}

Hasil kesenjangan antarwilayah menurut klasifikasi wilayah analisis tipologi klassen pada tahun 2019 (tabel 5). Terdapat 4 jenis kelompok pola dan struktur ekonomi, diantaranya; kelompok pertama yaitu daerah maju dan tumbuh cepat, kelompok kedua yaitu daerah berkembang cepat, kelompok ketiga yaitu daerah maju tertekan, dan kelompok keempat yaitu daerah tertinggal.

Hasil penelitian ini yang menggunakan data PDRB atas dasar harga konstan tahun 


Volume : 06
Nomor $: 03$
Bulan $:$ September
Tahun $: 2020$
http $\quad: / /$ ejurnal.pps.ung.ac.id/index.php/Aksara

2015-2019 yang telah dirata-ratakan, yaitu pertumbuhan dan data PDB per kapita di setiap kabupaten/kota dalam wilayah Provinsi Bali. Terdapat 3 daerah dalam kelompok pertama yaitu daerah maju dan tumbuh cepat diantaranya kabupaten Badung, Gianyar dan kota Denpasar. Ada 2 daerah yang termasuk ke dalam kelompok ketiga yaitu daerah maju tapi tertekan diantaranya, kabupaten Tabanan dan Buleleng. 4 daerah tersisa yaitu kabupaten Jembrana, Klungkung, Bangli dan Karangasem termasuk ke dalam kelompok keempat yaitu daerah (relatif) tertinggal.

Berdasarkan penelitian sebelumnya (Raeskyesa et al, 2019) dari tahun 2010 hingga 2016, kabupaten Badung dan kota Denpasar termasuk kelompok pertama yaitu wilayah maju dan tumbuh cepat, sedangkan kabupaten Gianyar dan Buleleng termasuk ke dalam kelompok kedua yaitu daerah berkembang cepat dan sisanya yaitu kabupaten Tabanan, Jembrana, Klungkung, Bangli dan Karangasem dalam kelompok keempat yaitu daerah tertinggal.

Keterkaitan kedua penelitian ini dengan penelitian sebelumnya menunjukkan adanya ketimpangan atau kesenjangan antarwilayah di Provinsi Bali. Namun jika dibandingkan dari tahun terakhir 2016 dengan tahun terakhir 2019 terjadi perubahan pergeseran yang lebih baik. Beberapa daerah yang mengalami perubahan diantaranya, kabupaten Gianyar dari daerah berkembang cepat meningkat menjadi daerah maju dan tumbuh cepat. Kabupaten Buleleng termasuk ke dalam daerah berkembang meningkat menjadi daerah maju tapi tertekan. Kabupaten Tabanan merupakan daerah (relatif) tertinggal meningkat menjadi daerah maju tapi tertekan.

\subsection{Analisis Ketimpangan Sektor Lapangan Usaha}

Analisis ketimpangan atau kesenjangan sektor dilihat dari hasil klasifikasi sektor lapangan usaha berdasarkan analisis tipologi klassen pada tahun 2019 (tabel 6). Menurut tipologi klassen, terdapat 4 jenis kelompok pola dan struktur ekonomi, diantaranya; kelompok pertama yaitu sektor unggulan (prima), kelompok kedua yaitu sektor berkembang, kelompok ketiga yaitu sektor potensial, dan kelompok keempat yaitu sektor terbelakang.

Hasil penelitian ini yang menggunakan data PDRB 17 sektor lapangan usaha atas dasar harga konstan tahun 2015 sampai 2019 yang telah dirata-ratakan, yaitu pertumbuhan dan data PDB per kapita di setiap kabupaten/kota dalam wilayah Provinsi Bali. Terdapat 5 sektor yang termasuk ke dalam kelompok pertama yaitu sektor unggulan (prima) diantaranya: konstruksi, transportasi dan pergudangan, informasi dan komunikasi, serta perdagangan besar dan eceran; reparasi mobil dan motor. Ada 4 sektor dalam kelompok ketiga yaitu sektor berkembang diantaranya: pertanian; kehutanan dan perikanan, industri pengolahan, jasa keuangan dan asuransi, serta real estate. Lima sektor yang termasuk kelompok ketiga yaitu sektor potensial diantaranya: administrasi pemerintahan; pertahanan dan jaminan social wajib, jasa perusahaan, jasa pendidikan, jada kesehatan dan kegiatan social, serta jasa lainnya. Sektor-sektor lainnya diantaranya: sektor pertambangan dan penggalian, pengadaan listrik dan gas, serta pengadaan air; pengelolaan sampah dan daur ulang, dalam kelompok sektor keempat yaitu sektor terbelakang.

Menurut penelitian Raeskyesa et al, (2019) analisis sektor-sektor potensial dari tahun 2010 hingga 2016 di wilayah Provinsi Bali dengan kelompok pertama yaitu sektor unggulan (prima) diantaranya : konstruksi, penyediaan akomodasi makan minum, informasi dan komunikasi, jasa keuangan dan asuransi, jasa kesehatan dan kegiatan social, pengadaan listrik dan gas, serta perdagangan besar dan eceran; reparasi mobil dan motor. Kelompok kedua yaitu sektor berkembang diantaranya : administrasi pemerintahan; pertahanan dan jaminan social wajib 


$\begin{array}{ll}\text { Volume }: 06 \\ \text { Nomor }: 03 \\ \text { Bulan } & : \text { September } \\ \text { Tahun } & : 2020 \\ \text { http } & : / / \text { ejurnal.pps.ung.ac.id/index.php/Aksara }\end{array}$

serta jasa lainnya. Kelompok ketiga yaitu sektor potensial diantaranya : industri dan sektor transportasi dan pergudangan. Kelompok keempat yaitu sektor terbelakang diantaranya : pertambangan dan penggalian, sektor jasa perusahaan, sektor pertanian; kehutanan dan perikanan, serta sektor pengadaan air; pengelolaan sampah; limbah dan daur ulang.

Keterkaitan kedua penelitian ini dengan penelitian sebelumnya menunjukkan adanya ketimpangan atau kesenjangan perkembangan sektor ekonomi antarwilayah di Provinsi Bali. Namun jika dibandingkan adanya perubahan pergeseran beberapa sektor dari tahun terakhir 2016 dengan tahun terakhir 2019 diantaranya, sektor administrasi pemerintahan; pertahanan dan jaminan social, sektor pertanian; kehutanan dan perikanan, sektor jasa perusahaan dan sektor jasa lainnya mengalami peningkatan. Sedangkan sektor real estate, sektor pengadaan listrik dan gas, sektor industry pengolahan, sektor jasa pendidikan, sektor jasa keuangan dan asuransi, serta sektor jasa kesehatan dan kegiatan social mengalami penurunan.

\subsection{Keterkaitan Ketimpangan dengan Nilai Index Williamson (IW)}

Pengukuran ketimpangan atau kesenjangan ekonomi antarwilayah di Provinsi Bali menggunakan metode penentuan nilai Indeks Williamson. Penilaian dilakukan dengan cara melihat nilai akhir Indeks Williamson, jika nilainya mendekati nol atau semakin kecil nilaikanya, maka semakin rendah tingkat ketimpangan ekonomi. Begitupula sebaliknya, semakin besar angka Indeks Williamson, maka semakin tinggi pula tingkat ketimpangan ekonomi. Data PDRB atas harga konstan tahun periode 2016-2019 yang telah dirataratakan digunakan dalam penelitian ini, yaitu pertumbuhan dan data PDB per kapita di setiap kabupaten/kota dalam wilayah Provinsi Bali. Nilai Indeks Williamson yang didapatkan yaitu sebesar 0.26 pada tahun 2019. Nilai yang didapatkan tersebut menunjukkan nilai yang cukup baik, walaupun hampir mendekati nol, namun masih lebih dari nol, sehingga dapat digolongkan sedang.

Perbandingan nilai Indeks Williamson penelitian ini dengan penelitian sebelumnya (Raeskyesa, 2019) pada periode 2010-2015 mengalami penurunan yaitu sebesar 0.7 yang masih lebih tinggi dari nilai Indeks Williamson pada periode 2016-2019. Begitupula dilihat dari hasil nilai klasifikasi tipologi klassen antarwilayah dan sektor lapangan usaha terdapat beberapa perubahan pergeseran kenaikan golongan. Walaupun masih terdapat beberapa wilayah dan sektor yang masih termasuk dalam golongan tertinggal atau terbelakang, sehingga tetap saja disarankan untuk pemerintah Provinsi Bali, agar meratakan pembangunan di semua wilayah Provinsi Bali. Pemerintah dapat memfokuskan pada daerah dengan sektor tertinggal atau terbelakang agar dapat lebih berkembang, begitupula daerah dengan sektor berkembang dapat dijadikan daerah dengan sektor potensial di masa mendatang. Daerah yang sudah memiliki sektor unggulan tetap dipertahankan untuk tahun-tahun berikutnya. Sehingga proses pembangunan merata yang nyata dapat terwujudkan pada seluruh wilayah di Provinsi Bali.

\section{Simpulan}

Berdasarkan hasil analisis tipologi klassen dan Indeks Williamson dapat disimpulkan bahwa :

1. Hasil tipologi klassen menunjukkan bahwa wilayah Provinsi Bali digolongkan sebagai daerah maju tetapi tertinggal. Daerah yang termasuk daerah maju yaitu kabupaten Badung, Gianyar, Tabanan, Buleleng dan kota Denpasar. Sisa 4 daerah lainnya ternasuk daerah tertinggal. 


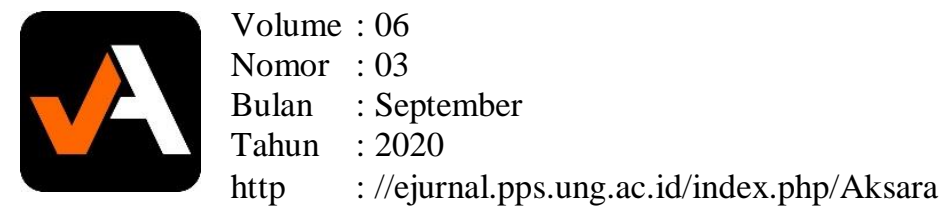

2. Hasil analisis berdasarkan 17 sektor lapangan usaha di Provinsi Bali yang termasuk sektor unggulan diantaranya sektor konstruksi, penyediaan akomodasi makan minum, informasi dan komunikasi, jasa keuangan dan asuransi, jasa kesehatan dan kegiatan social, pengadaan listrik dan gas, serta perdagangan besar dan eceran; reparasi mobil dan motor.

3. Hasil Indeks Williamson dari 9 kabupaten/kota di Provinsi Bali memiliki nilai ketimpangan Indeks Williamson sebesar 0.26 pada tahun 2019 yang menunjukkan nilai yang cukup baik dengan adanya penurunan tingkat ketimpangan ekonomi dibandingkan dengan penelitian di tahun sebelumnya.

4. Pemerataan pembangunan tetap harus diperhatikan dengan memfokuskan pada wilayah dan sektor yang masih termasuk tertinggal atau terbelakang, sehingga proses pembangunan dapat terjadi pada semua wilayah kabupaten/kota di Provinsi Bali.

\section{Daftar Pustaka}

Yuendini, E. P., Rachmi, I. N., Puspitasari, N. A., Harini, R. \& Alfana, M. A. F. A. (2019). Analisis Potensi Ekonomi Sektor Pertanian dan Sektor Pariwisata di Provinsi Bali Menggunakan Teknik Analisis Regional. Jurnal Geografi, 16(2):128-136.

Wiranatha, A. S., Antara M. \& Suryawardani, I. G. A. O. (2017). Impact of Tourism Leakage on the Growth of Economic Sectors, Employment and Income Distribution in Bali, Indonesia. International Journal of Economic Reasearch, ISSN : 0972-9380, Vol. 14, No. 8.

Wiguna, I. M. G. S. \& Budhi, M. K. S. (2019). Analisis Sektor Unggulan dan Potensi Pertumbuhan Ekonomi di Kabupaten Badung Tahun 2012-216. E-Jurnal EP Unud, 8[4] : 810-841.

Raeskyesa, D. G. S., Suryandaru, R. A. \& Kadarusman, Y. B. (2019). Analysis on Growth Pattern and Economic Sectors in Bali Province". Jurnal Ilmu Manajemen \& Ekonomika, Vol. 11, No.2, 45-56.

Tallo, A. J., Arianti, S. P., A. F., Bahri, A. S., Heryanto, S., Fassa, F., Prihandrijanti, M. \& Anshory, B. J. (2018). Typology Analysis and Leading Sector of East Nusa Tenggara Province in 2017. Journal of Physics : Conf Series 1114.

Sukwika, T. (2018). Peran Pembangunan Infrastuktur terhadap Ketimpangan Ekonomi Antarwilayah di Indonesia. Jurnal Wilayah dan Lingkungan, Volume 6 No.2 : 115-130. 
Volume : 06

Nomor : 03

Bulan : September

Tahun : 2020

http : //ejurnal.pps.ung.ac.id/index.php/Aksara

248 AKSARA: Jurnal IImu Pendidikan Nonformal 